no distal swelling or pain in the metacarpophalangeal or interphalangeal joints and where it is usually easy to flex the finger fully but difficult to straighten it again.

The natural history of diabetic cheiroarthropathy is not clear but the joint contractures may not improve. ${ }^{35}$ There have been no reports of the benefit of tenolysis, and our case shows that allowing full movements of the finger joint may prevent secondary joint contracture and that the pain and swelling settle over six to nine months.

${ }^{1}$ Fraser, D M, et al, Diabetes, 1979, 28, 96.

2 British Medical fournal, 1975, 4, 369.

${ }^{3}$ Benedetti, A, and Noacco, C, Acta Diabetologica Latina, 1976, 13, 54.

${ }^{4}$ Ravid, M, Dinai, Y, and Sohar, E, Acta Diabetologica Latina, 1977, 14, 170.

${ }^{5}$ Grgic, A, et al, New England fournal of Medicine, 1975, 292, 372.

(Accepted 7 August 1979)

Victoria Hospital, Kirkcaldy, Fife KY2 5AH

I R ROBERTSON, MB, CHB, medical registrar

P M EARNSHAW, MRCP, medical registrar

I W CAMPBELL, MRCP, consultant physician

\section{Eclampsia in a patient who had had a renal transplant}

Pregnancy is uncommon in patients on maintenance haemodialysis, but occurs more often in those who receive successful renal transplants. The European Dialysis and Transplantation Association's figures for 1978 show that up to 31 December 1977 there have been 79 live births to such recipients. ${ }^{1}$ There have also been 73 surgical or spontaneous abortions reported. The former are usually performed for hypertension or deteriorating renal function, or both, but the reasons for the latter are not clear. We here report the rapid development of eclampsia and abortion in a patient who had had a renal transplant.

\section{Case report}

A 14-year-old girl presented in 1973 with hypertension and the nephrotic syndrome due to mesangiocapillary glomerulonephritis. Her renal function deteriorated slowly and haemodialysis was started in May 1977. In August 1977 she received a cadaveric renal transplant (with no HLA antigens in common) which functioned well after three rejection episodes. Her hypertension recurred after transplantation and she had occasional asymptomatic urinary tract infections. In March 1979, after five months months' amenorrhoea, a pregnancy test was positive. Her pregnancy progressed well without deterioration in renal function or blood pressure. In June 1979, a about 30 weeks gestation, she complained of headaches, nausea, and vomiting. Her general practitioner, finding her unconscious and greatly hypertensive, injected diazepam intramuscularly and sent her to hospital. On admission her blood pressure was $170 / 130 \mathrm{~mm} \mathrm{Hg}$, she was oedematous, having fits, and responding only to painful stimuli. Fundoscopy showed normal appearances and there were no focal neurological signs. The fetal heart was not heard. The eclampsia was controlled with infusions of diazepam and hydrallazine. A macerated fetus was delivered several hours later after $\mathbb{W}$ intravenous infusion of prostaglandin $\mathrm{E}_{2}$ and the fits ceased. She made a complete clinical recovery. Her renal function was unimpaired throughout her admission apart from a transient increase in proteinuria to $1 \mathrm{~g} / 24 \mathrm{~h}$. $\mathrm{Q}$ She has remained well and has been advised against further pregnancies. $C$ Necropsy of the fetus showed a macerated girl weighing $2193 \mathrm{~g}$ but no other abnormality.

\section{Comment}

Renal transplantation aims at rehabilitating the patient fully, $\mathbb{D}$ including restoration of fertility in both men and women. The risks to mother and fetus of pregnancy after renal replacement have been $\mathrm{s}$ reviewed. ${ }^{23}$ In the mother they are poor control of blood pressure, $\vec{O}$ deterioration in renal function, and possible need for caesarean $\vec{\overrightarrow{ }}$ section owing to cephalopelvic disproportion secondary to renal $\vec{\omega}$ osteodystrophy or transplant obstruction. The risk of rejection is apparently not increased. Fetal risks include leucopenia and adreno- 3 cortical insufficiency. Fears of teratogenesis due to immunosuppressive i drugs are as yet unfounded ${ }^{4}$ but the risk for future generations is unknown. Abnormalities, albeit short lived, in the chromosomes of $\vec{\varphi}$ the peripheral blood lymphocytes have been reported, and damage to fetal germ cells will take years to declare itself. Theoretically, however, the fetus should be protected from the effects of azothiaprine since it $N$ lacks the enzyme inosinate pyrophosphorylase required to convert $\frac{\mathrm{O}}{3}$ azothiaprine to thioinosinic acid, the metabolite active on dividing $N$ cells. ${ }^{5} \mathrm{~A}$ pregnant woman who has had a renal transplant needs close observation and monitoring before and after delivery. In our patient the risk of developing pre-eclampsia was high, since she was young, primiparous, and hypertensive; but she developed rapid and fulminating eclampsia at a relatively early stage of pregnancy. One week before admission she was well, normotensive, and without oedema or appreciable proteinuria. Though surgical and sprntaneous abortions are not uncommon in this group of patients, we have been unable to find a report of a case of eclampsia in a recipient of a renal transplant.

${ }^{1}$ Combined Report on Regular Dialysis and Transplantation in Europe, VIII, 1977, Proceedings of the European Dialysis and Transplantation Association, 1978, 15, 4.

2 British Medical fournal, 1976, 1, 733.

${ }^{3}$ Lancet, 1978, 1, 861 .

McGeown, M G, and Nevin, N C, Proceedings of the European Dialysis and Transplant Association, 1978, 15, 384

${ }^{5}$ Papoff, P, et al, Canadian Medical Association fournal, 1977, 117, 1288.

(Accepted 17 August 1979)

Western General Hospital, Edinburgh EH4 2XU

P F WILLIAMS, MA, MRCP, registrar in renal and general medicine I JELEN, FRCSED, MRCOG, senior registrar in obstetrics and gynaecology

\section{Vancouver style}

All manuscripts submitted to the $B M f$ from now on should conform to the uniform requirements for manuscripts submitted to biomedical journals (known as the Vancouver style).

The $B M F$, together with many other international biomedical journals, has agreed to accept articles prepared in accordance with the Vancouver style and will be introducing the system from January 1980. The style (described in full in BMf, 24 February, p 532) is intended to standardise requirements for authors and covers text format, presentation of methods and results, use of SI units, and the form of tables and illustrations. All the participating journals have also agreed to introduce a standard form of references.

In future references to papers submitted to the $B M \mathcal{F}$ should include: the names of all authors if there are fewer than seven or, if there are more, the first three followed by et al; the title of journal articles or book chapters; the titles of journals abbreviated according to the style of Index Medicus; and the first and final page numbers of the article or chapter.

Examples of common forms of references are

${ }^{1}$ International Steering Committee of Medical Editors. Uniform requirements for manuscripts submitted to biomedical journals. Br Med F 1979; 1, 532-5.

2 Soter NA, Wasserman SI, Austen KF. Cold urticaria: release into the circulation of histamine and eosinophil chemotactic factor of anaphylaxis during cold challenge. $N$ Engl Med 1976; 294: 687-90.

3 Weinstein L, Swartz MN. Pathogenic properties of invading microorganisms. In: Sodeman WA Jr, Sodeman WA, eds. Pathologic physiology: mechanisms of disease. Philadelphia: W B Saunders, 1974: 457-72.

Up to the beginning of October some 100 journals had agreed to accept articles in the Vancouver style, and a full list will be printed early in 1980 . 